\title{
PEREMPUAN DALAM INDEKS PEMBANGUNAN MANUSIA (KAJIAN IPM-IPG DAN IDG SUMBER KEMENPP TAHUN 2019)
}

\author{
Urip Giyono ${ }^{(1)}$ \\ Maemunah ${ }^{(2)}$ \\ ${ }^{(1)}$ Dosen Fakultas Hukum Universitas Muhammadiyah Cirebon

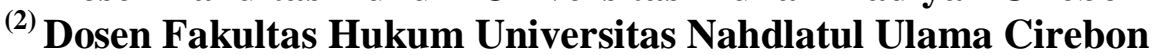 \\ uripgiyono03061968@ gmail.com ${ }^{(\mathbf{1})}$ \\ mayy60@yahoo.co.id ${ }^{(2)}$
}

\begin{abstract}
ABSTRAK
Perempuan, dalam kaitan dengan pembangunan dan hasil pembangunan selalu menarik jika dikaji dan dibanding- bandingkan antar tahun maupun antar Kabupaten /Kota.Dari tahun ke tahun perempuan selalu ada peningkatan dalam perannya di berbagai bidang, Kementerian Pemberdayaan Perempuan selalu meliris hasil dari pembangunan, dan bagaiman peran dalam pembangunan. Dengan data yang ada di Kementerian Pemberdayaan Perempuan, penulis membuat perbandingan dengan kabupaten yang ada di wilayah propinsi dan dengan capian di tingkat Propinsi, berdasarkan data yang didapat tersebut disandingkan dengan data dari Kabupaten /kota yang dijadikan bahan untuk lokasi kajian, maka terlihat posisi perempuan dalam berbagai bidang yang menghasilkan Indeks pembangunan Manusia, Indeks Pembangunan Gender dan Indeks pemberdayaan Gender. Untuk Kabupaten Kuantan Singingi Tahun 2019, bahwa perempuan di kabupaten tersebut sudah cukup maju, dibanding dengan kabupaten yang se wilayah dan lahirnya lebih dulu. inilah yang menarik dari kab. Kuantan Singingi. Dengan hasil Indek Pembangunan Manusia sabagai berikut : perempuan dalam Indeks Pembangunan Manusia UHH dan ALS ada di atas laki- laki, RTS dan pengeluaran perkapita ada dibawah laki- laki. Indeks Pembangunan Gender berada pada angka 90,06 berada diatas kab. Rokan Hulu dan diatas Propinsi Riau, Untuk Indeks Pembangunan Gender berada di angka 61,63 dibawah Kab. Meranti, dan Propinsi. Dengan kajian ini dapat mengambil point-point untuk bagaimana kedepan dalam pemberdayaan perempuan khususnya di Kabupaten Kuantan Singingi.
\end{abstract}

Kata Kunci : Peran Perempuan, IPM, IPG dan IDG. 


\section{JURNAL JENDELA HUKUM}

ISSN Cetak E Online : 2355-5831/ 2355-9934

\section{A. PENDAHULUAN}

Perempuan, apa yang terjadi dengan perempuan, masih ada sebagian perempuan, tertekan, tidak berani, mengalah, mendapat kekerasan, dianggap lemah, merasa lemah, terpaksa bicara, dipaksa bicara. Partisipasi Perempuan dalam pembangunan selalu dibincangkan, mengapa partisipasi laki- laki tidak dibincangkan, padahal mungkin saja, banyak kaum laki- laki yang tidak memahami tentang pembangunan, mungkin saja ada kaum laki - laki yang hanya ikut menikmati, itulah istimewanya perempuan.

Kabupaten Kuantan Singingi berpenduduk 326.266 jiwa(2017) dengan sebaran 62/km2 memiliki 15 Kecamatan, 11 Kelurahan dan 218 Desa, luas Wilayah $5.259,36 \mathrm{~km}^{2}$.

Berdiri sejak tahun 1999, dengan mayoritas penduduk beragama Islam hampir 95,41\%, selebihnya kristen, budha dan hindu. Perkembangan Kabupaten Kuantan Singing yang begitu pesat, sejak memisahkan diri dari Indragiri Hulu tertanggal 8 Oktober 1999, mengalami perkembangan yang begitu pesat, keadaan alam, merupakan sumber daya alam, yang begitu menggiurkan bagi pendatang, sumber daya manusia yang berkualitas . banyak orang- orang besar, alim ulama di lahirkan dari Kuantan Singingi, anak- nak muda remaja yang berprestasi, Religius, adat istiadat yang sangat kental dan kuat dilaksanakan oleh masyarakat di Kuantan
Singingi merupakan modal besar, ide-ide cemerlang yang dilahirkan dari Kabupaten yang baru seusia anak SMP (10 tahun) dengan berkembangnya masyarakat dan pembangunan yang dilakukan mulai terasa oleh masyarakat, berpengaruh terhadapa kehidupan.

Nah, dalam pembangunan yang begitu pesat bagaimana posisi perempuan Kuantan Singingi, apakah sudah berpartisipasi dengan maksimal, atau masih minim prestasi, ini sangat erat kaitannya dengan kesetaraan dan keadilan gender.

Kesetaraan dan keadilan gender di kuantan Singingi, dengan budaya, adat istiadat yang kuat, agama yang cukup kuat, bagaimana hasil dari kajian- kajian dan analisa yang dilakukan oleh Kementerian Pemberdayaan Perempuan. Gender, apa itu gender, bila ada kegiatan kaitan dengan gender pasti, kata-kata yang muncul adalah ini sih ibu A, ini yang harus hadir Ibu $\mathrm{B}$, terus yang seharusnya seperti apa. gender tidak dimaknai sebagai perbedaan fisik antara laki-laki dan perempuan dalam arti biologis. Pemaknaan gender pada perbedaan peran laki-laki dan perempuan, perilaku, yang dikonstruksikan secara sosial. Kesetaraan Gender adalah kesamaan kondisi bagi perempuan dan laki-laki untuk memperoleh kesempatan dan mendapatkan hak- haknya sebagai 
manusia, agar mampu berperan dan berpartisipasi dalam kegiatan politik, ekonomi, sosial budaya, pertahanan dan keamanan, dan kesamaan dalam menikmati hasil pembangunan.

Kesetaraan gender dapat dicapai dengan meningkatkan pelibatan perempuan dalam proses pembangunan, sejak menyusun perencanaan, melaksanakan pembangunan , memantau jalannya pembangunan sampai mendapatkan manfaat dari program pembangunan tersebut.

Dalam mengukur kesetaraan gender tersebut, ada 3 indeks yang digunakan yaitu IPM, IPG, dan IDG. Indeks Pembangunan Manusia (IPM) merupakan ukuran kualitas hidup manusia dalam bidang kesehatan, pendidikan, maupun ekonomi. Ukuran tersebut kemudian digunakan untuk mengukur Indeks Pembangunan Gender (IPG) yang difokuskan pada faktor ketidaksetaraan antara laki-laki dan perempuan di berbagai level. Sedangkan Indeks Pemberdayaan Gender (IDG) mengukur partisipasi aktif perempuan pada kegiatan ekonomi yaitu dengan indikator persentase sumbangan perempuan dalam pendapatan kerja, kegiatan politik dengan indikator keterlibatan perempuan di parlemen, serta dalam pengambilan keputusan melalui indikator perempuan sebagai tenaga manajer, professional, administrasi, teknisi. Kesimpulannya, IDG digunakan untuk melihat sejauh mana pencapaian kapabilitas perempuan dalam berbagai bidang kehidupan ${ }^{1}$.

I. Metoda Yang Digunakan

Untuk dapat mendeskripsikan, mengkaji dan menganalisa, penulis menggunakan literatus bacaan tentang perempuan, pemberdayaan perempuan dan data dari Kementrian Pemberdayaan Perempuan, Kunatan Singin dalam angka serta data yang bersumber dari Badan Pusat Statistik. Dengan menggunakan data dan informasi dari berbagai sumber, penulis mendeskripsikan, mengkaji dan menganalisa serta menyimpulkan untuk memberikan saran program dan kegiatan yang tepat untuk dilakukan di Kunatan Singing dengan kondisi yang ada.

II. Tujuan Penelitian

Untuk mengetahui kondisi dan posisi perempuan di Kuantan Singingi, kekurangan dan kelebihan dalam IPM, IDG dan IPG

III. Manfaat Penelitian

Yang menjadi focus lokasi adalah Kuantan Singing, Kuantan Singingi sebagai kabupaten yang termuda yang terdiri dari berbagai suku, dalam melakukan program dan kegiatan pasti ada nilai minus dan plus nya. Dengan kajian ini akan lebih terarah dalam memilih program - program dan kegiatan

\footnotetext{
1 Kemenpp, Pembangunan Manusia Berbasis Gender, 2018
} 
JURNAL JENDELA HUKUM

ISSN Cetak E Online : 2355-5831/ 2355-9934

dalam peningkatan pemberdayaaan perempuan.

\section{B. PEMBAHASAN}

Pembahasan akan mencakup Indeks Pembangunan Manusia, Indeks Pemberdayaan manusia dan Indeks Pembangunan Manusia, sebagai berikut :

\section{Indeks Pembangunan Manusia}

Indeks Pembangunan Manusia (IPM) atau Human Development Index (HDI) adalah pengukuran perbandingan dari harapn hidup,melek hurup,pendidikan dan standar hidup untuk semua negara di seluruh dunia. $^{2}$

IPM digunakan untuk mengklasifikasikan apakah sebuah negara adalah negara maju, negara berkembang atau negara terbelakang dan juga untuk mengukur pengaruh dari kebijakan ekonomi terhadap kualitas hidup. ${ }^{3}$

Unsur- unsur apa saja yang tercantum dalam Indeks Pembangunan manusia :

1. Angka harapan hidup, yakni perkiraan rata- rata tambahan umur seseorang yang diharapkan dapat terus hidup, atau dapat didefinisikan sebagai rata- rata jumlah tahun yang dijalani oleh seseorang setelah orang tersebut mencapai ulang tahun yang ke $\mathrm{x}$. Ukuran yang lazim digunakan adalah angka harapan hidup saat lahir yang mencerminkan kondisi kesehatan

pada saat itu, sehingga apabila membicarakan angka harapn hidup, adalah rata- rata jumlah tahun yang akan dijalani oleh seseorang sejak orang tersebut lahir ${ }^{4}$

2. Konsep definisi Angka harapan hidup, atau umur harapan hidup, adalah rata - rata tahun hidup yang masih akan dijalani oleh seseorang yang telah berhasil mencapai umur $\mathrm{x}$, pada suatu tahun tertentu, dalam situasi mortalitas yang berlaku di lingkungan masyarakatnya.

Idealnya angka harapan hidup dihitung berdasarkan angka kematian menurut umur yang datanya diperoleh dari catatan registrasi kematian secara bertahun- tahun sehingga memungkinkan dibuat tabel kematian. Keguanaan AHH. Merupakan alat untuk mengevaluasi kinerja pemerintah dalam meningkatkan kesejahteraan penduduk pada umumnya, dan meningkatkan derajat kesehatan pada khusunya. Angka harapan hidup yang rendah disuatu daerah harus diikiuti dengan program pembanguna kesehatan, dan program sosial lainnya termasuk kesehatan lingkungan, kecukupan gizi dan kalori

\footnotetext{
${ }^{2}$ Wikipedia

${ }^{3}$ Wikipedia
}

${ }^{4}$ Lakadata, 


\section{IURNAL JENDELA HUKUM}

ISSN Cetak E Online : 2355-5831/ 2355-9934

termasuk progam pengentasan kemiskinanan $^{5}$

1. Harapan lama sekolah :

Harapan lama sekolah didefinisikan sebagai lamanya sekolah (dalam tahun ) yang diharapkan akan dirasakan oleh anak pada umur tertentu di masa yang akan datang

Kegunaan: HLS dapat digunakan untuk nengetahui kondisi pembangunan sistem pendidikan di berbagai jenjang.

2. Rata - rata lama sekolah :

Rata- rata lama sekolah (RLS) didefinikan sebagai jumlah tahun yang akan digunakan oleh penduduik dalam menjalanani pendidikan formal Kegunaan dapat digunakan untuk mengetahui kualitas pendidikan masyarakat dalam suatu wilayah ${ }^{6}$

3. Pengeluaran perkapita :

Pengeluaran perkapita adalah biaya yang dikeluarkan untuk konsumsi semua anggota rumah tangga selama sebulan dibagi dengan banyaknya anggota rumah tangga. ${ }^{7}$

Kegunaan data pengeluaran dapat mengungkap tentang pola konsumsi rumah tangga secara umum menggunakan indikator proporsi pengeluaran untuk makanan dan non makanan. Komposisi pengeluaran rumah

${ }^{5}$ Sirusa.bps.go.id
${ }^{6}$ Sirusa.bps.go.id
${ }^{7}$ Sirusa.bps.go.id tangga dapat dijadikan ukuran untuk menilai tingkat kesejahteraan ekonomi penduduk, makin rendah presentasi pengeluaran untuk makanan terhadap total pengeluaran makin membaik tingkat kesejahteraan ${ }^{8}$

\section{Indeks Pembangunan Gender (Ipg)}

Digunakan untuk mengukur pencapaian dimensi dan variabel yang sama seperti IPM, tetapi mengungkap ketidakadilan pencapaian laki- laki dan perempuan, semakin mendekati angka 100 maka kesenjangan pembangunan antara perempuan dan laki-laki semakin kecil.

Komponen didalamnya mencakup :

a. Umur Harapan Hidup

b. Harapan Lama Sekolah

c. Rata- Tara Lama Sekolah

d. Pengeluaran Perkapita.

\section{Indeks Pemberdayaan Gender (Idg)}

Indeks pemberdayaan gender (IDG) memperlihatkan sejauh mana kesetaraan gender dalam hal peran aktif perempuan dalam kehidupan dinia politik, pengambilan keputisan dan ekonomi. Peran aktif perempuan. Indikator ini menunjukan apakah perempuan dapat memainkan peranan aktif dalam kehidupan ekonomi dan politik.

Komponen didalam nya mencakup:

1. Keterlibatan perempuan di parlemen

\footnotetext{
${ }^{8}$ Sirusa.bps.go.id
} 


\section{JURNAL JENDELA HUKUM}

ISSN Cetak E Online : 2355-5831/ 2355-9934

Untuk meningkatkan partisipasi perempuan dalam politik dilakukan dengan ditetapkannya Undang-undang No 10 Tahun 2008. Dalam UU tersebut, dijelaskan bahwa sekurang-kurangnya harus ada 30 persen keterwakilan perempuan pada kepengurusan partai politik tingkat pusat dan bakal calon anggota DPR/DPRD lembaga legislatif. Meski belum mampu memenuhi target yang diharapkan, tapi dengan tren keterwakilan perempuan di parlemen yang cenderung meningkat telah menimbulkan optimisme bahwa peran perempuan di bidang politik semakin nyata terlihat dan berpotensi untuk terus ditingkatkan.

2. Perempuan sebagai tenaga manajer, profesional, adminstrasi, teknisi Kaum wanita masih ada yang menganggap bahwa, wanita kaum lemah yang selalu butuh perlindungan laki- laki. Maka nya masih ada yang menganggap bahwa wanita tidak layak jadi pemimpin. Dengan alasan bahwa laki- laki langkahnya panjang, pikirannya luas, laki- laki lebih kuat, lebih rasional dan lebih bijak, hal itulah kemungkinan yang menyebabkan perempuan dalam hal- hal kepemimpinan masih tertinggal. Namun saat ini sudah banyak kaum wanita yang menjadi manajer, tenaga profesional dan tenaga teknisi, yang dahuulu masih sangat langka.
3. Sumbangan perempuan dalam pendapatan kerja.

Kesenjangan capaian antara laki-laki dan perempuan di pasar tenaga kerja merupakan fenomena yang umum terjadi terutama di negara-negara berkembang. Perbedaan upah yang diterima menjadi salah satu hal yang paling sering terjadi. Kesenjangan dalam upah pada akhirnya berimbas pada munculnya kesenjangan dalam sumbangan pendapatan kaum perempuan.

\section{Hasil Kajian Perempuan Kuantan} Singingi Berdasarkan Data Kemenpp Tahun 2019

\section{a. Indeks Pembangunan Manusia (Ipm)}

Indeks Pembangunan Manusia Nasional Tahun 2019 ada pada angka 71,39 tertinggi propinsi DKI Jakarta yakni 80,47 , dan terendah Papua yakni 60,06. Sedangkan Propinsi Riau 71,79 tahun 2017 dan 72,44 tahun 2018, Propinsi Riau ada pada posisi ke 6 pada tahun 2017 dengan angka 71,79 dan tahun 2018 rangking tetap ke 6 dengan angka 72,44

Dengan angka masing - masing komponen adalah sebagai berikut : 
ISSN Cetak E Online : 2355-5831/ 2355-9934

IPM Kuantan Singingi :

\begin{tabular}{|l|l|c|c|}
\hline No & \multicolumn{1}{|c|}{ Uraian } & LK & PR \\
\hline 1 & UMUR & 66,22 & 70,09 \\
& $\begin{array}{l}\text { HARAPAN } \\
\text { HIDUP (UHH) }\end{array}$ & & \\
\hline 2 & $\begin{array}{l}\text { HARAPAN } \\
\text { LAMA } \\
\text { SEKOLAH } \\
\text { (HLS) }\end{array}$ & 12,86 & 13,52 \\
\hline 3 & $\begin{array}{l}\text { RATA-RATA } \\
\text { LAMA } \\
\text { SEKOLAH }\end{array}$ & 8,70 & 8,01 \\
& $\begin{array}{l} \\
\text { (RLS) }\end{array}$ & & \\
\hline 4 & $\begin{array}{l}\text { PENGELUARAN } \\
\text { PERKAPITA }\end{array}$ & 15561 & 7.916 \\
\hline
\end{tabular}

Sumber : KemenPP

IPM Kota Pekan Baru tertinggi di

Propinsi Riau :

\begin{tabular}{|l|l|c|c|}
\hline No & \multicolumn{1}{|c|}{ Uraian } & LK & \multicolumn{1}{c|}{ PR } \\
\hline 1 & $\begin{array}{l}\text { UMUR } \\
\text { HARAPAN } \\
\text { HIDUP (UHH) }\end{array}$ & 69,93 & 73,82 \\
\hline 2 & $\begin{array}{l}\text { HARAPAN } \\
\text { LAMA } \\
\text { SEKOLAH } \\
\text { (HLS) }\end{array}$ & 15,36 & 15,10 \\
\hline 3 & $\begin{array}{l}\text { RATA-RATA } \\
\text { LAMA } \\
\text { SEKOLAH } \\
\text { (RLS) }\end{array}$ & 11,47 & 11,13 \\
\hline 4 & $\begin{array}{l}\text { PENGELUARAN } \\
\text { PERKAPITA } \\
\text { PP) }\end{array}$ & 21.320 & 13,099 \\
\hline
\end{tabular}

Sumber : KemenPP
IPM Indragiri hilir terendah di Propinsi

Riau

\begin{tabular}{|l|l|c|c|}
\hline No & Uraian & LK & PR \\
\hline 1 & $\begin{array}{l}\text { UMUR } \\
\text { HARAPAN } \\
\text { HIDUP (UHH) }\end{array}$ & 65,30 & 69,22 \\
\hline 2 & $\begin{array}{l}\text { HARAPAN } \\
\text { LAMA } \\
\text { SEKOLAH } \\
\text { (HLS) }\end{array}$ & 11,89 & 12,28 \\
\hline 3 & $\begin{array}{l}\text { RATA-RATA } \\
\text { LAMA } \\
\text { SEKOLAH } \\
\text { (RLS) }\end{array}$ & 7,49 & 6,87 \\
\hline 4 & $\begin{array}{l}\text { PENGELUARAN } \\
\text { PERKAPITA } \\
\text { PP) }\end{array}$ & 16811 & 5179 \\
\hline
\end{tabular}

Sumber : KemenPP

Capaian Indeks Pembangunan Manusia dan posisi Kabupaten Kuantan Singingi secara terpisah laki- laki dan perempuan adalah sebagai berikut :

Capaian IPM laki - laki :

1. Kota Pekan Baru $\quad: 84,75$

2. Kab. Siak : 78,47

3. Kota Dumai $\quad: 77,88$

4. Kab. Bengkalis : 77,39

5. Kab.Kampar : $: 77,02$

6. Kab. Pelalawan : 76,17

7. Kab. Rokan Hulu : 75,98

8. Kab. Indragiri Hulu : 74,08

9. Kab, Kuantan Singingi : 74,03

Kabupaten Kuantan sisingi berada di peringkat 9 dari 12 Kabupten Koat se Propinsi Riau. 
Capaian IPM perempuan :

1. Kota Bekan Baru : 78,79

2. Kota Dumai : 70,73

3. Kab. Bengkalis $: 69,62$

4. Kab. Siak : 69,46

5. Kab.Kampar $: 68,77$

6. Kab. Pelalawan $: 67,41$

7. Kab, Kuantan Singingi : 66,67

Untuk IPM perempuan Kabupaten

Kuantan Singingi berada di rangking 7 dari

12 Kabupaten Kota di Propinsi Riau. Indeks Pembangunan Manusia terdiri dari 4 komponen, yaitu Umur Harapan Hidup (UHH), Harapan Lama Sekolah(HLS), Rata- Rata Lama Sekolah (RLS) dan Pengeluaran Perkapita, bila melihat dari unsur - unsur yang menentukan jumlah nilai, Kabupaten Kuantan Singingi capaian komponen adalah sebagai berikut :

1. Umur Harapan Hidup, capaian per Kabupaten sebagai berikut :

Untuk laki - laki

1. Kota Bekan Baru : 69,93

2. Kab. Bengkalis : 68,83

3. Kab. Siak : 68,77

4. Kab. Pelalawan : 68,73

5. Kota Dumai : 68,54

6. Kab.Kampar : 68,34

7. Kab. Indragiri Hulu $: 67,95$

8. Kab. Rokan Hilir $\quad: 67,83$

9. Kab. Rokan Hulu $\quad: 67,52$

10. Kab, Kuantan Singingi $\quad: 66,22$
Kabupaten Kuantan Singing ada di peringkat 10 untuk umur harapan hidup pada laki- laki.

Untuk Perempuan :

1. Kota Bekan Baru : 73,82

2. Kab. Bengkalis : : 72,76

3. Kab. Siak : 72,7

4. Kab. Pelalawan : 72,65

5. Kota Dumai : 72,46

6. Kab.Kampar : 72,26

7. Kab. Indragiri Hulu : 71,89

8. Kab. Rokan Hilir $\quad: 71,79$

9. Kab. Rokan Hulu : 71,46

10. Kab, Kuantan Singingi : 70,09

Kabupaten Kuantan Singing ada di peringkat 10 untuk umur harapan hidup pada perempuan, namun nilai perempuan lebih tinggi dibanding laki- laki, ada di angka 70,09 untuk perempuan dan 66,22 untuk laki- laki.

2. Harapan Lama Sekolah

Untuk laki- laki sebagai berikut :

1. Kota Pekan baru : 15,36

2. Kab. Rokan Hulu $: 13,35$

3. Kab. Kampar $: 13,14$

4. Kab. Siak : 12,87

5. Kab. Kaunsing $\quad: 12,86$

Untuk Perempuan sebagai berikut:

1. Kota Pekan Baru $\quad: 15.1$

2. Kab. Bengkalis $: 13,72$

3. Kab. Kuantan Singing : 13,5

Harapan lama sekolah kabupaten Kuantan Singingi $(12,86)$ untuk laki- laki 
berada pada rangking 5 dan pekan baru yakni rata - rata pendidikan perempuan $(13,52)$ ada pada ranking 3.

menengah yakni11,13,

3. Rata- rata lama Sekolah

4. Pengeluaran Perkapita :

Untuk laki - laki sebagai berikut :

Pengeluaran perkapita untuk laki-

1. Kota Pekan Baru

$: 11,47$

2. Kota Dumai

$: 10,05$

3. Kab. Siak

$: 9,82$

4. Kab. Bengkalis

$: 9,56$

5. Kab. Kampar

$: 9,41$

6. Kab. Pelalawan

$: 8,9$

7. Kab. Rokan Hulu

$: 8,73$

8. Kab. Kuantan Singingi $: 8,7$

Kabupaten Kuantan Singing 8,7 untuk Rata- rata Lama Sekolah berada pada ranking ke 8 , artinya rata - rata lama sekolah masih menduduki Sekolah Menengah Pertama, teringgi ada di Kota pekan baru yakni rata - rata pendidikan menengah yakni11,47.

Rata- rata lama Sekolah Untuk Perempuan :

1. Kota Pekan Baru $: 11,13$

2. Kota Dumai $: 9,61$

3. Kab. Siak $: 9,44$

4. Kab. Bengkalis

$: 8,86$

5. Kab. Kampar

$: 8,87$

6. Kab. Pelalawan

$: 8,1$

7. Kab. Rokan Hulu

$: 8,06$

8. Kab. Kuantan Singingi $: 8,01$

Kabupaten Kuantan Singing 8,01 untuk Rata- rata lama Sekolah berada pada ranking ke 8 , artinya rata - rata lama sekolah masih menduduki Sekolah Menengah Pertama, teringgi ada di Kota laki:

1. Kota Pekan baru : 21320

2. Kab. Siak

: 18819

3. Kab. Pelalawan

: 18654

4. Kota Dumai

$: 17642$

5. Kab. Bengkalis

: 17413

6. Kab. Rokan Hulu

: 16877

7. Kab. Kampar

$: 16838$

8. Kab. Indragiri hilir

: 16811

9. Kab. Indragiri hulu

$: 16472$

10. Kab. Kuansing

$: 15561$

Kabupaten Kuansing pengeluaran perkapita untuk laki- laki ada pada rangking ke 10, dengan 15561, ter tinggi ada di Pekan Baru dengan 21320.

Pengeluaran per kapita untuk Perempuan :

1. Kota Pekan baru : 13099

2. Kota Dumai

: 9000

3. Kab. Pelalawan

: 8513

4. Kab. Siak

: 8436

5. Kab. Bengkali

: 8318

6. Kab. Kampar

: 8259

7. Kab. Kuansing

: 7916

Kabupaten Kuansing pengeluaran perkapita untuk perempuan ada pada ranking ke 7, dengan 7916, ter tinggi ada di Pekan Baru dengan 13099, untuk ranking pengeluaran perkapitan lebih tinggi dari laki- laki yang berada pada 
urutan 10 dari 12 Kabupaten Kota se Propinsi Riau.

Dengan data diatas menunjukan bahwa Kabupaten Kuantan Singingi dalam pencapaian Indeks Pembangunan manusia berada pada rangking yang tinggi/besar, dari 4 komponen setelah terpilah laki- dan perempuan, hanya harapan lama sekolah perempuan yang masuk ranking 3 , dan lakilaki masuk ranking 5, selebihnya berada diatas 5 besar, dan yang paling rendah ada 3 ( tiga ) komponen yakni umur harapan hidup baik laki- laki maupun perempuan ada pada rangking 10. Begitu juga pengeluaran perkapita laki- laki ada di peringkat 10 .

Untuk IPM ,capaian kaum perempuan di Kabupaten Kuantan Singing unggul dalam dua hal yakni harapan lama sekolah dan pengeluaran perkapita dibanding laki - laki.

\section{A. Indeks Pembangunan Gender ( Ipg )}

Indeks Pembangunan Gender, merupakan bilangan atau angka IPM yang terpilah antara laki- laki dan perempuan. Berikut data IPG berdasarkan kajian dari KemenPP tahun 2019.

IPG Nasional : 90,99, Propinsi Riau berada di angka 88,37 dengan peringkat 28, Kabupaten Kuantan Singingi berada di angka 90,06 peringkat 3, Kota Pekan baru tertinggi yakni 92,97 dan Kota Dumai peringkat 2 dengan angka 90,82, dan yang terendah kabupaten Rokan Hulu 81,85 .

Dengan angka masing - masing sebagai berikut :

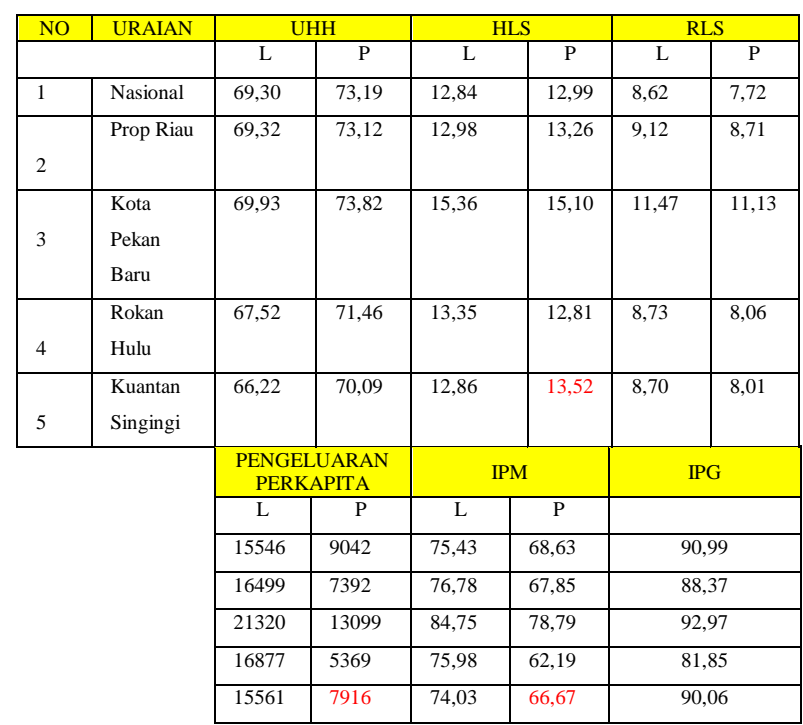

Sumber : KemenPP

Data diatas mengambarkan khusus untuk perempuan :

1. Kabupaten Kuantan Singingi, Umur Harapan Hidup lebih rendah dari Kabupten Rokan Hulu sebagai predikat terendah, Kota Pekan Baru diatas rata- rata Propinsi dan Nasional

2. Kabupaten Kuantan singing, Harapan Lama Sekolah lebih tinggi dari Kabupaten Rokan Hulu, Propinsi Riau maupun Nasional

3. Kabupaten Kuantan Singingi, Ratarata Lama Sekolah ada dibawah Kabupaten Rokan Hulu, Kota Pekan Baru, Propinsi Riau. Sedangkan untuk nasional dibawah Kabupaten Kuantan Singingi

4. Kabupaten Kuantan Singingi dalam Pengeluaran Perkapita ada diatas 
Kabupaten Rokan Hulu dan Propinsi Riau.

\section{B. Indeks Pemberdayaan Gender ( Idg)}

Kabupaten Kuantan singingi dengan 35 anggota DPRD, dan anggota DPRD perempuan hanya 1 orang, inilah gambaran yang ada Kabupaten Kuantan Singingi yang begitu kental adat istiadat, budaya dan masyarakat yang sangat religius, dalam pelibatan perempuan di parlemen masih sangat rendah, selanjutnya bagaimana untuk Propinsi Riau ada 12 orang perempuan yang pada periode sebelumnya 18 orang perempuan., dari 65 anggota, artinya didominasi oleh kaum lakilaki untuk periode ini.

Kodisi IDG dibanding dengan Kabupaten/Kota lain di Propinsi Riau dan capaian tingkat nasional.

\begin{tabular}{|l|l|l|l|l|l|}
\hline No & Kab/Kota & $\begin{array}{c}\text { Perempuan } \\
\text { Di } \\
\text { Parlemen }\end{array}$ & $\begin{array}{c}\text { Perempuan } \\
\text { Sbg } \\
\text { Tenaga } \\
\text { Prof }\end{array}$ & $\begin{array}{l}\text { Sumbangan } \\
\text { Pendapatan } \\
\text { Perempuan }\end{array}$ & IDG \\
\hline 1 & Nasional & 17,32 & 47,02 & 36,70 & 72,10 \\
\hline 2 & $\begin{array}{l}\text { Propinsi } \\
\text { Riau }\end{array}$ & 28,13 & 51,95 & 28,14 & 75,73 \\
\hline 3 & $\begin{array}{l}\text { Kuantan } \\
\text { Singingi }\end{array}$ & 5,71 & 48,74 & 36,55 & 61,63 \\
\hline 4 & $\begin{array}{l}\text { Kep. } \\
\text { Meranti }\end{array}$ & 16,67 & 42,75 & 26,84 & 64,86 \\
\hline 5 & Siak & 5,00 & 49,30 & 19,66 & 45,58 \\
\hline
\end{tabular}

Data diatas menunjukan Propinsi

Riau ada diatas nasional, ranking di Propinsi Riau adalah kabupaten Kep. Meranti, dan terendah kabupaten Siak. Untuk kabupaten Kuantan Singing bada pada ranking 3 .
Dari data diatas :

1. Dibanding dengan capaian Nasional Kabupaten Kunatan Singingi :

- Perempuan di Parlemen ada dibawah capaian Nasional dan Propinsi Riau

- Perempuan sebagai tenaga profesional ada di atas capaian nasional, namun dibawah Propinsi Riau

- Sumbangan pendapatan perempuan ada dibawah nasional namun ada di atas Propinsi Riau.

Secara keseluruhan IDG Kabupaten Kuantan Singing berada di bawah nasional dan Propinsi Riau.

2. Dibanding dengan capaian Kabupaten Kep. Meranti :

- Perempuan di Parlemen ada dibawah capaian Kabupaten Kep. Meranti

- Perempuan sebagai tenaga profesional ada di atas capaian Kabupaten Kep. Meranti

- Sumbangan pendapatan perempuan ada diatas Kabupaten Kep. Meranti

3. Dibanding dengan capaian Kabupaten Siak :

- Perempuan di Parlemen ada diatas capaian Kabupaten Siak.

- Perempuan sebagai tenaga profesional ada di bawah capaian Kabupaten Siak

- Sumbangan pendapatan perempuan ada diatas Kabupaten Siak 
Dalam komponen perempuan diparlemen masih menggunakan data akhir periode 2014-2019.

\section{KESIMPULAN :}

Kabupaten Kuantan Singingi dalam program dan kegiatan perempuyan masih harus di pacu lagi, untuk dapat mensejajarkan dengan Kota/ kabupaten yang sudah tinggi capaiannnya. Saran dalam penelitian ini sebagai berikut :

1. Lakukan sosialisasi tentang pemberdayaan perempuan bukan hanya oleh pemerintah, tapi dilakukan sejak kecil dalam keluarga dan pendidikan usia dini.

2. Program yang dilakukan bersifat kontinyu, evaluasi perlu dilakukan, dan pendampingan dalam program-program yang baru.

3. Perlunya kesinambungan dalam melaksanakan program.

4. Perlunya pendampingan bagi pengusaha perempuan pemula,sampai mandiri dan melibatkan perguruan tinggi serta pihak swasta.

5. Perlu diprioritaskan beasiswa bagi perempuan yang punya minat dan bakat.

\section{DAFTAR BACAAN}

Buku Bacaan : Tentang Perempuan, Kondisi Perempuan

Jurnal : Tentang Kesetaraan Dan Keadilan Gender.

Kajian dan Analisa tentang Pembanguna Manusia berbasis Gender, KemenPP 2019.

Data Badan Pusat Statistik Propinsi Riau 